\section{The Quaternary}

In late July 2007, some 1100 Quaternary scientists gathered for a week-long conference in the tropical city of Cairns in northeast Australia for the 17th quadrennial congress of the International Union for Quaternary Research (INQUA). Conference presentations were on topics in such diverse fields as archaeology, stratigraphy, geomorphology, palaeontology, geochemistry, hydrology, climate change and geochronology. To an outsider, the unifying theme of an INQUA Congress may be difficult to grasp, but diversity has always been a characteristic of Quaternary research, more so than for any other major period of the geological time scale.

The volume and breadth of Quaternary research can be gauged by the fact that there are four major international journals in the English language that include Quaternary in their titles, each containing exclusively Quaternary material: Quaternary International, Quaternary Research, Journal of Quaternary Science and Quaternary Science Reviews, the latter having one of the highest impact factors of any earth science journal. Two other journals in English, Boreas and The Holocene also contain exclusively Quaternary material, as do several journals in non-English languages, e.g. Géographie physique et Quaternaire (French, Canada), Quaternaire (French), Eiszeitalter und Gegenwart (German), Il Quaternario (Italian) and Cuaternario y Geomorfologia (Spanish). There is also a recently published Encyclopedia of Quaternary Science (Ed. S. Elias) in 4 volumes and over 3000 pages which is an excellent up-to-date source of information on the Quaternary. It is also worthy of note that, in 2007, INQUA became a full member union of the International Council for Science, the only geological time period to have its own union.

This Special Issue of Episodes contains a selection of papers that we hope will convey to readers something of the diversity of Quaternary research, with 15 papers grouped according to 4 major themes:

1. Humans and the Quaternary. As highlighted in the papers by Clague and Dennnell, although the Quaternary spans only a fraction of the 4.5 billion years of Earth history, it is disproportionately important because it is the interval during which humans evolved and because it includes the present. In both these papers we are reminded of the powerful influence of climate change on human activities, including those of the past, present and future.

2. Quaternary stratigraphy. The Quaternary has long been known as the period of the ice-ages, though, as discussed by Ehlers \& Gibbard, we now know that evidence of Cenozoic glaciation extends well beyond the Quaternary. Similarly, Dodonov \& Zhou demonstrate that while loess deposits in Asia represent one of the most complete continental records of the Quaternary, loess deposition has a history that extends back to the Miocene. However, compared to earlier geological periods the Quaternary offers better preservation of strata and greater stratigraphic resolution. Nowhere is this more evident than in ice cores from Antarctica which, as shown by Wolff, provide a detailed palaeoclimate record extending back some 800,000 years. The high- to ultra-highresolution record of rapid, global environmental changes, described by Hoek, that accompanied the transition from the last glacial to the present interglacial period, is an excellent example of the multi-disciplinary nature of Quaternary research. A global perspective on Quaternary stratigraphy is provided by Gibbard \& Cohen, centred on their chronostratigraphic correlation chart of the last 2.7 million years.

3. Definition of the Quaternary. Despite its long use as a chronostratigraphic subdivision of geological time, the formal definition of the Quaternary remains contentious including its duration and rank. In 2007, at the 17th INQUA Congress in Cairns, the general assembly of several hundred delegates unanimously supported the definition of the Quaternary as a Period/System with its base defined at the GSSP of the Gelasian Stage ( 2.6 Ma). The paper by Ogg \& Pillans, the two papers by Head, Gibbard \& Salvador and that by Lourens explore several scenarios for defining the Quaternary, recognising that the definition cannot be divorced from considering the definitions of the Pleistocene, Neogene and Tertiary. This will be a major topic of discussion at the 33rd International Geological Congress in Oslo in August 2008.

4. Subdivision of the Quaternary. Unlike the Pliocene and earlier epochs of the Geological Time Scale (GTS), there are currently no formally defined stages of the Pleistocene and Holocene. However, the Pleistocene has long been divided into Lower (Early), Middle and Upper (Late) Subepochs and there is renewed impetus to define formally stages within these subepochs. The paper by Cita summarises recent work towards defining Italian regional stages for the Pleistocene that could be adopted as international stages. The papers by Head, Pillans \& Farquhar, Litt \& Gibbard and Walker et al describe the progress of three working groups of the ICS Subcommission on Quaternary Stratigraphy towards defining formal Global Stratotype Sections and Points (GSSPs) for the Middle Pleistocene Subseries, Upper Pleistocene Subseries and the Holocene Series, respectively. The base of the Lower Pleistocene Subseries corresponds to the base of the Pleistocene and therefore is defined automatically by the latter. The proposal of Walker et al to define the Holocene GSSP in a Greenland ice-core is unique in the GTS. The Holocene is also the only remaining epoch in the GTS to be formally defined.

The editors would like to thank the many people who have made this special volume of papers possible. In particular we thank Jim Ogg for proposing the project, all the contributors and referees, and finally the Episodes Editor Zhenyu Yang and his staff for their tolerance and support that enabled us to produce this publication.

\section{Philip Gibbard and Brad Pillans}

